بررسى روند تغييرات كيفيت منابع آب زيرزمينى و ارزيابى شاخص IRWQIGC در بالادست سد زايندهرود

\author{
حسن ترابى يوده'، حجتالله يونسى 'و آزاده ارشيا؟

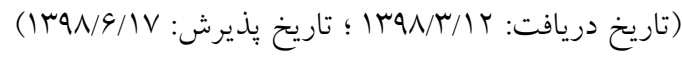

جكيده

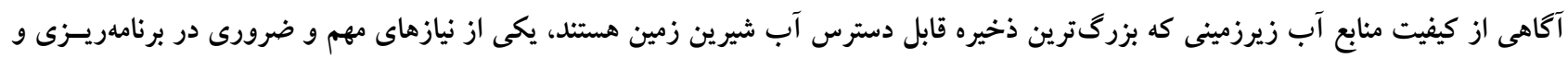

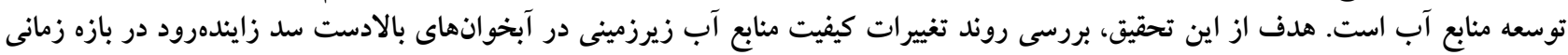

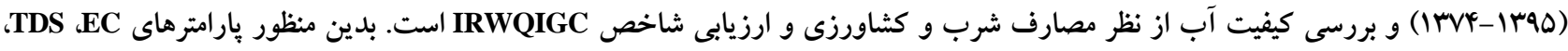

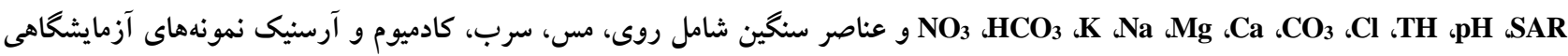

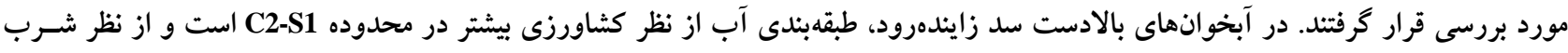

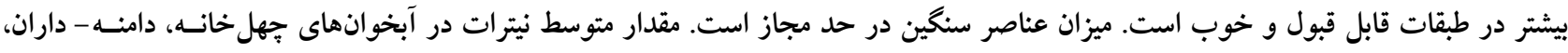

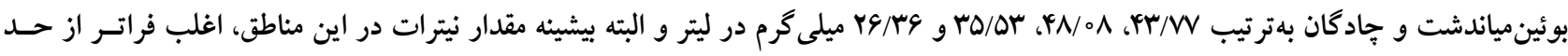

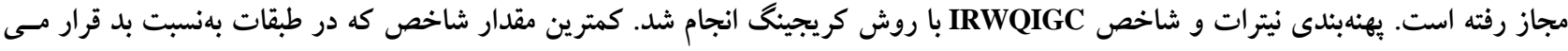

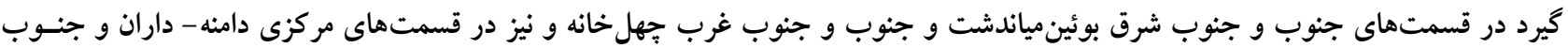

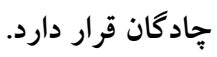

وازههاى كليدى: آب زيرزمينى، زايندرود، كريجينگ، IRWQIGC

ا. كروه مهندسى آب، دانشكده كشاورزى و منابع طبيعى، دانشخاه لرستان، خرمآباد

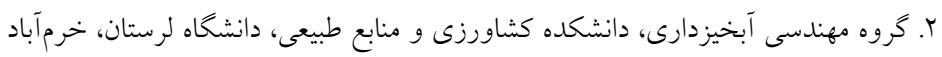

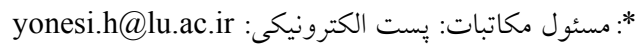




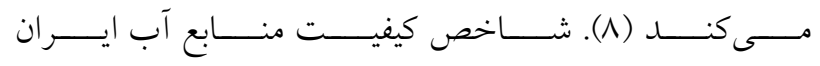
IRWQI (Iran Water Quality Index) روش مناسب با شرايط طبيعى و مسـائل منـابع آب ايسران تهيـه

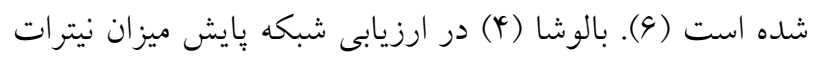

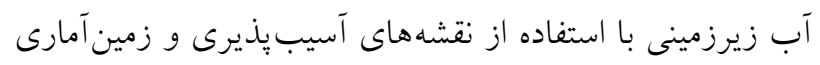

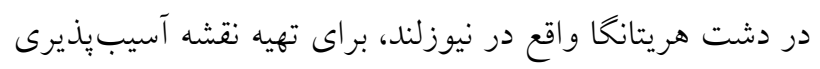

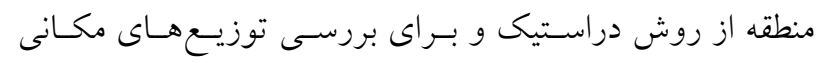

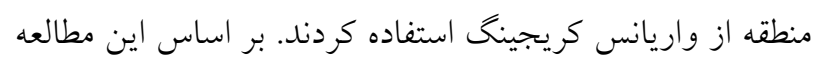

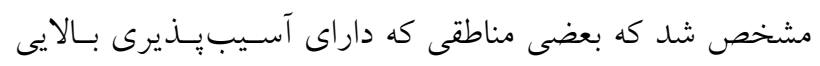

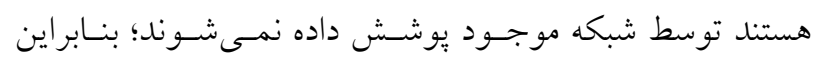

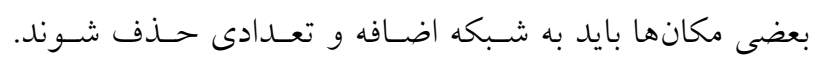

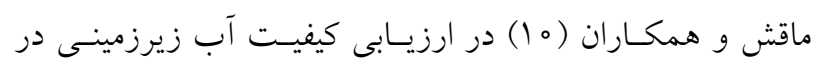

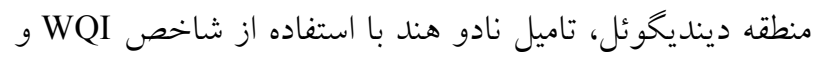

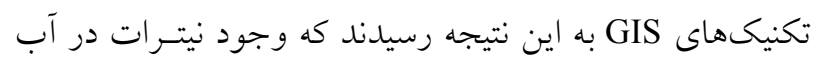

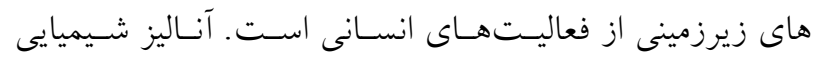

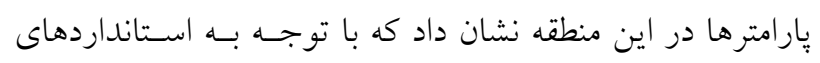

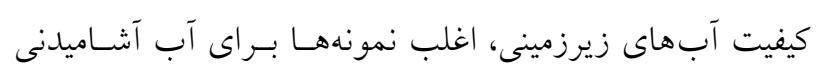

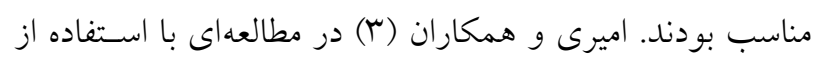

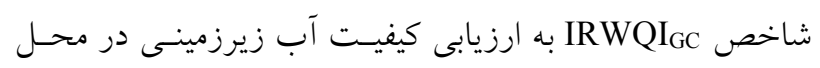

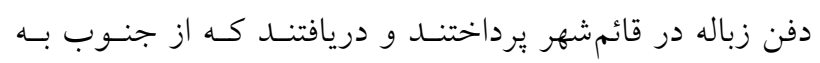

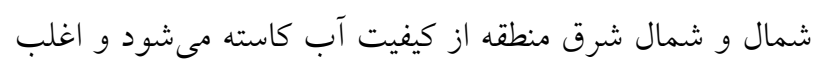

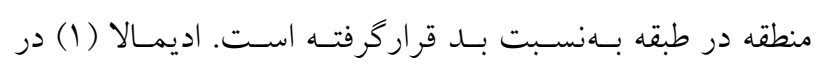

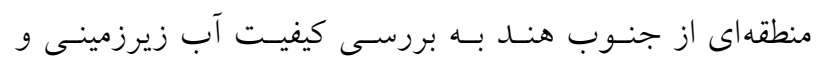

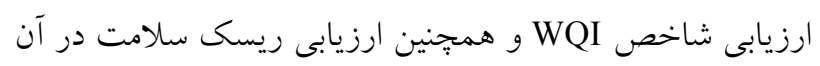

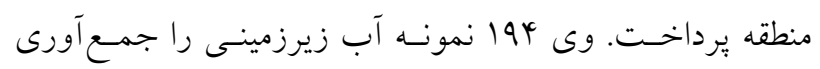

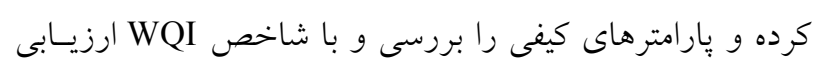

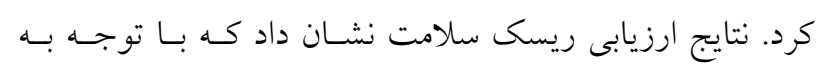

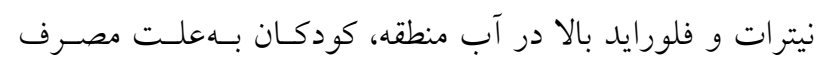

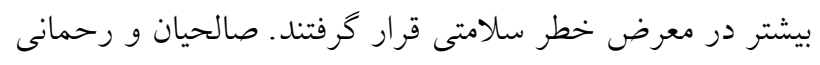

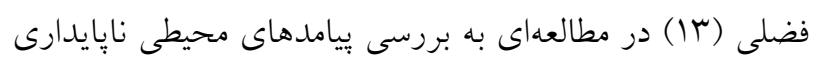

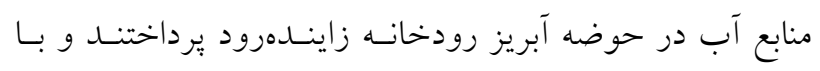

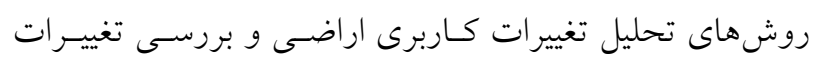

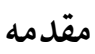

در سالهاى اخير برداشت بىرويه از منابع آب زيرزمينى عـلاوه

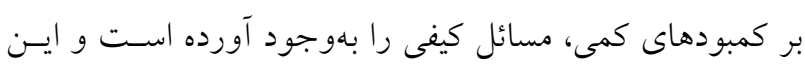

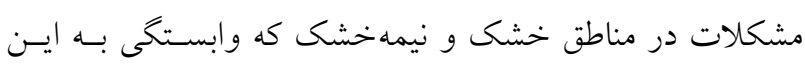

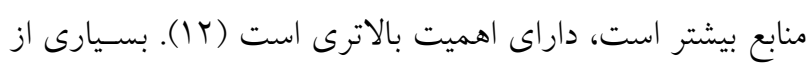

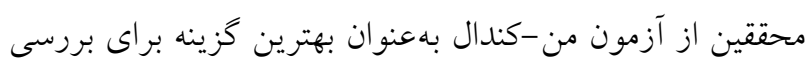

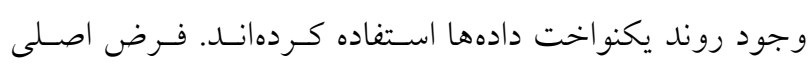

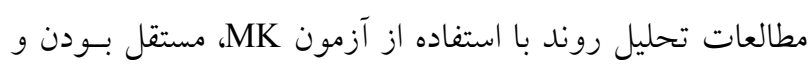

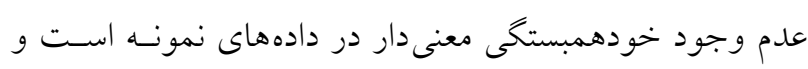

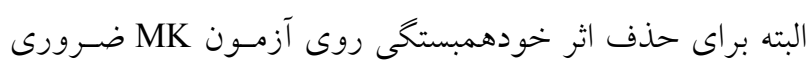

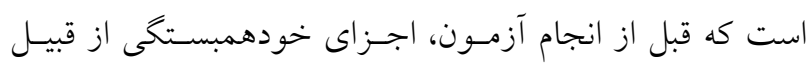

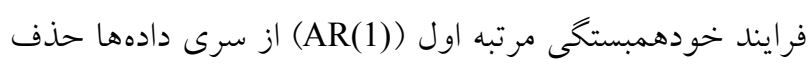
شود. اين فرايند بهاصطلاح ييش سفيد كـردن ناميـده مسى شئسود.

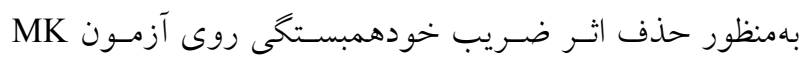

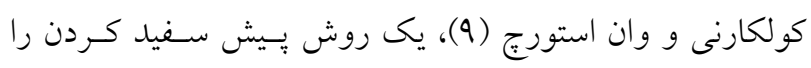

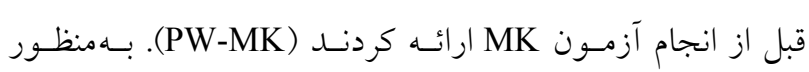

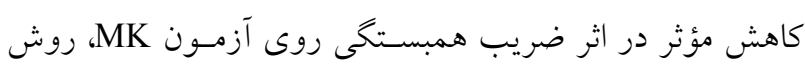

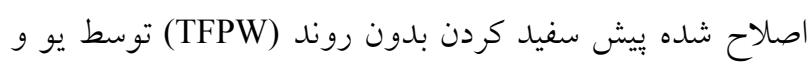

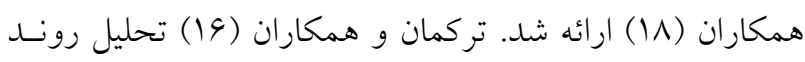

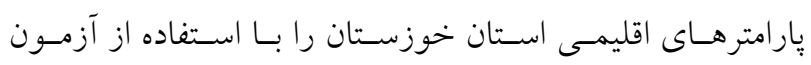
انجام دادند، نتـايج نشـاندهنـــه رونــــ معنـادار

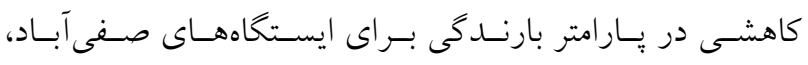

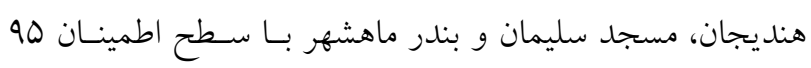

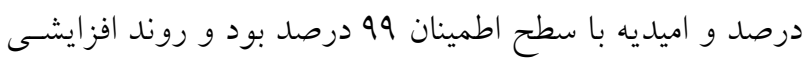

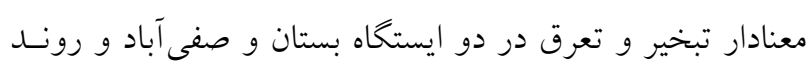

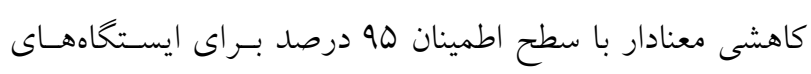

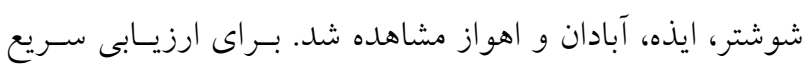

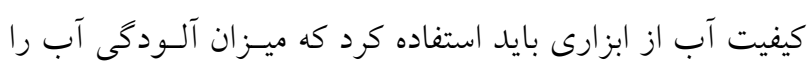

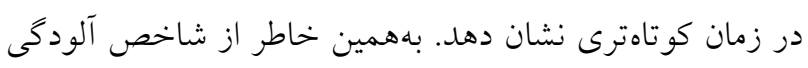

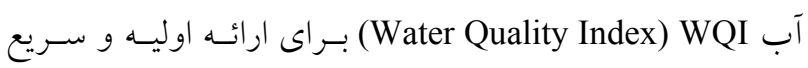

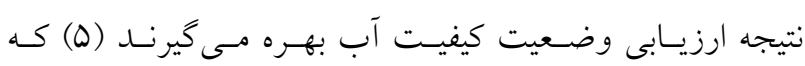

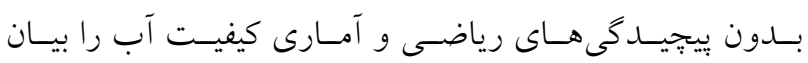



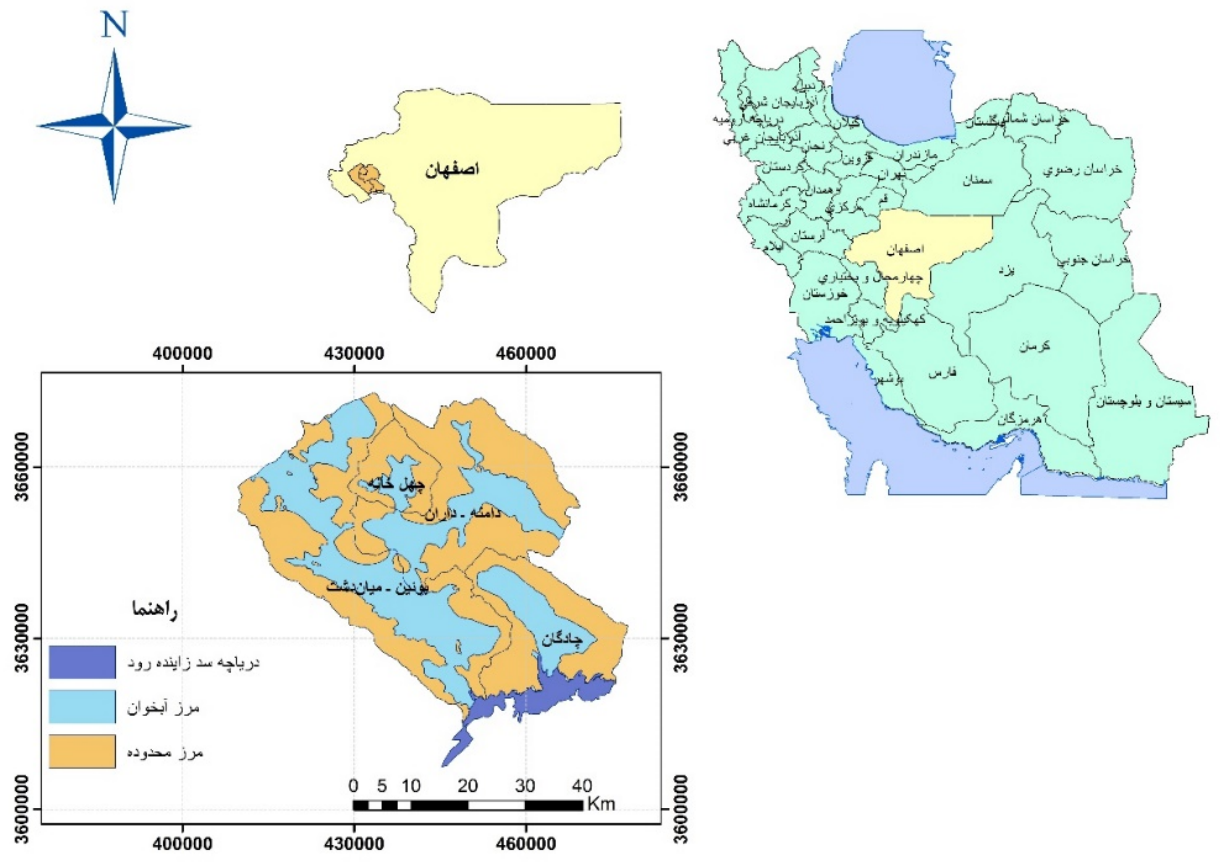

شكل ا. موقعيت محدوده مطالعاتى بالادست سد زايندهرود در استان اصفهان و ايران

روش تحقيق تعداد نمونههاى كيفى محدوده آبخــوانهـاى بالادسـت ســـ زايندهرود در آبخوانهاى بالادست سد زاينـدهرود كـهـ شـامل آبخـــوانهـاى جهل خانه، دامنه - دار ان، جاد كان و بوئين مياندشت است، شـركت

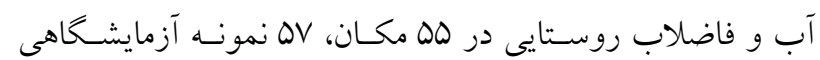

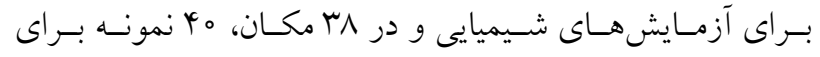
آزمايشهاى عناصر سنخين برداشت كـرده اسـت. شـركت آب و فاضلاب شهرى نيز در اين محدوده در ك مكان داراى سل نمونـه آزمايشخاهى است. شركت آب منطقهاى اصفهان نيز در بr نقطـه، 494 نمونه آزمايشخاهى برداشت كرده است. دانشخاه اصفهان نيـز در 04 مكان و براى هر مكان، دو نمونه در فصلهاى تر و خشك براى آزمايشهاى فيزيكوشيميايى و عناصر سنخين برداشت كـرده

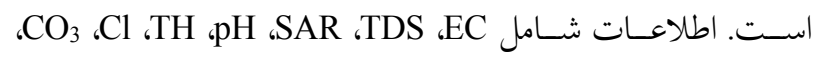

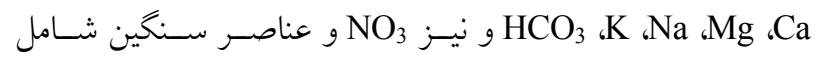
روى، مس، سرب، كادميوم و آرسـيك هسـتند. موقعيـت مكسانى

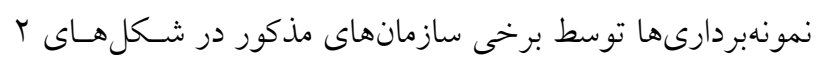
و ب آورده شده است.
برداشت از آب زيرزمينى و توزيع برسشـنامه، بيامـدهاى محيطى نايايدارى منابع آب در زايندهرود را بررسى كردند و نتـايج نشـان داد كه افزايش شدت خشكسـالى و تغييـرات كـاربرى اراضسى و فشار بر سفرههاى آب زيرزمينى، ييامدهاى محيطى نامناسبى را به دنبال داشته است. تحقيق حاضر با هدف ارزيابى رونـــ تغييـرات كيفيت منابع آب زيرزمينى و نيز محاسـبه و يهنسهبنـدى شـاخص

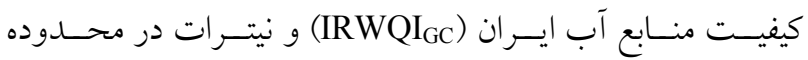
آبخوانهاى بالادست سد زايندهرود ارائه مىشود.

\section{مواد و روش ها منطقه موردمطالعه}

استان اصفهان با قرارگيرى در منطقه خشك و نيمه خشك مركزى يكى از استانهاى كم آب ايران است كه همواره تحت تأثير يديده خشكسالى بوده است. منابع آب شيرين اين استان محدود بــدهه و در سالهاى اخير نيز رشد جمعيت و بهـــبـــــارىهـاى غلـط از

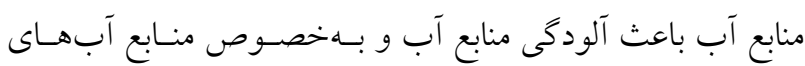

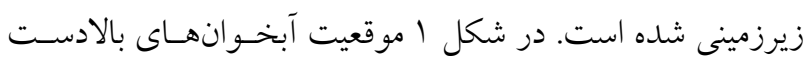
سد زايندهرود در استان اصفهان و ايران مشخص شده است. 


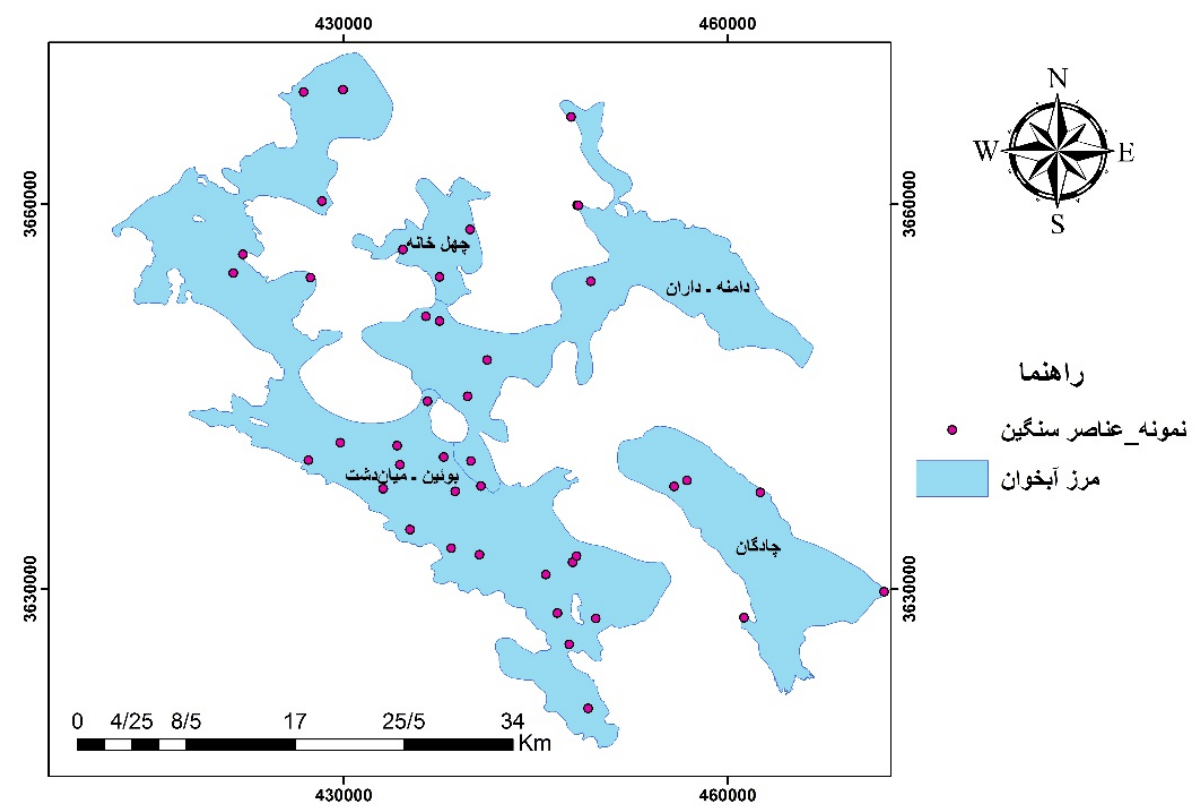

شكل r. مكانهاى نمونه گيرى عناصر سنخين توسط شركت آب و فاضلاب روستايى در محدوده آبخوانها

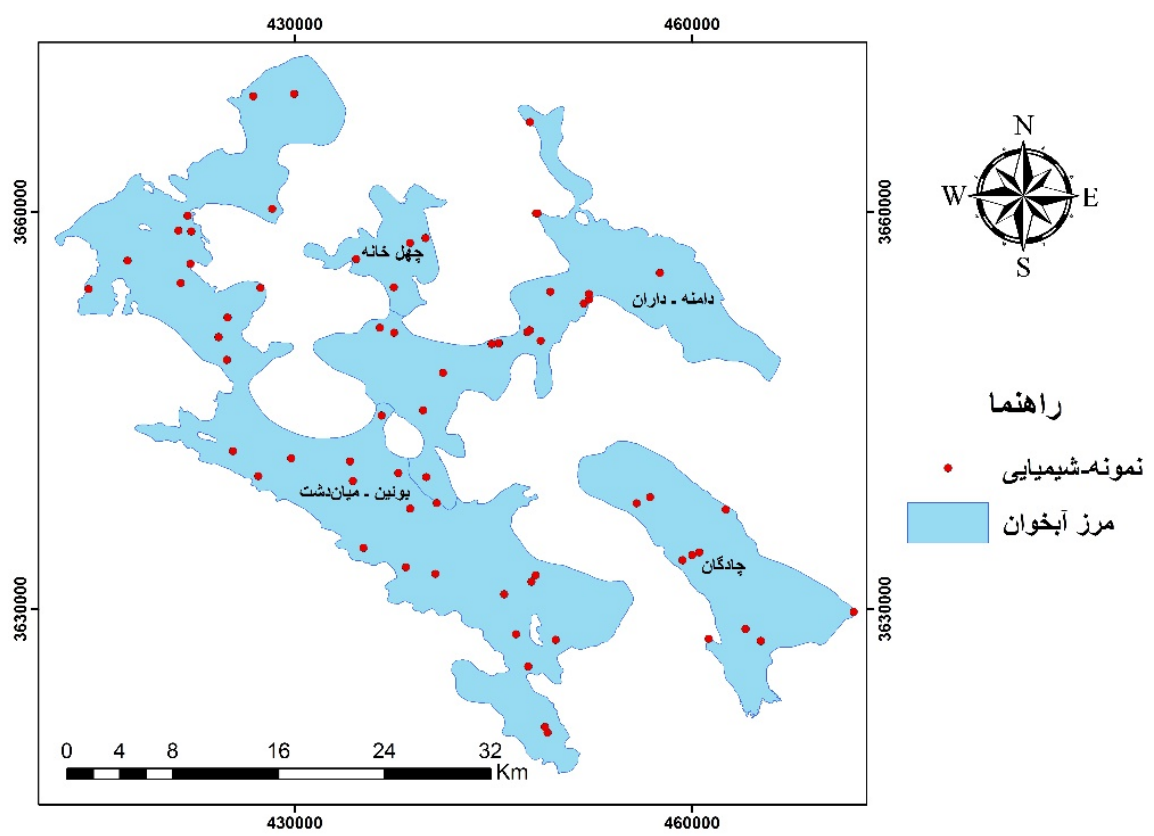

شكل r. مكانهاى نمونه گيرى نيترات و برخى پارامترهاى كيفى توسط شر كت آب و فاضلاب شهرى در محدوده آبخوانها

يكنواختى توزيع دادههاى نمونه و فرض مقابل H $H_{1}$ وجـود يـك روند يكنواخت در دادههاست. براى انجام اين آزمون ابتدا بايسـ

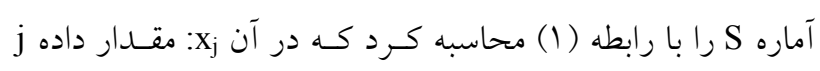

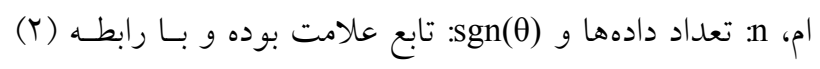

آزمون MK روى سرى زمانى بــدون حسـذف ضـريب خــود همبستخى (يشي سفيد نشده) آزمون MK يكى از يركاربرترين آزمونهاى غيريارامتريك براى ليى

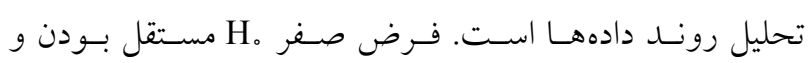


$r_{k}=\frac{\frac{1}{n-k} \sum_{t=1}^{n-k}\left[X_{t}^{\prime}-E\left(X_{t}^{\prime}\right)\right]\left[X_{t+k}-E\left(X_{t}^{\prime}\right)\right]}{\frac{1}{n} \sum_{t=1}^{n}\left[X_{t}^{\prime}-E\left(X_{t}^{\prime}\right)\right]^{2}}$

$E\left(X_{t}^{\prime}\right)=\frac{1}{n} \sum_{1}^{n} X_{t}^{\prime}$

ضريب خودهمبستخى مرتبه يك دادههاى نمونه سرى بـدون

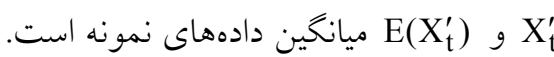

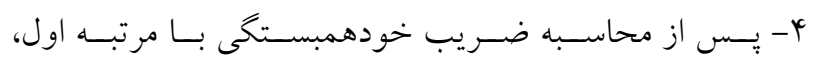

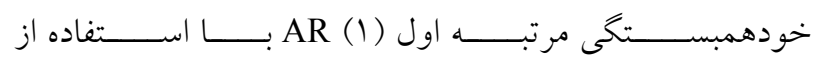
حذف مى شود. اين روش بيش سـفيد كـردن $Y_{t}^{\prime}=X_{t}^{\prime}-r_{1} X_{t-1}^{\prime}$

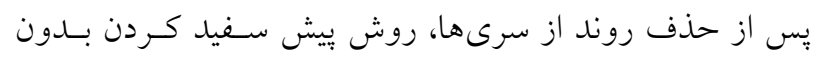

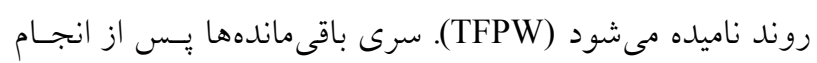

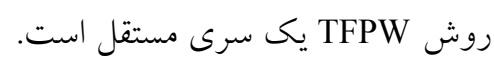
ه- روند شناخته شده Th و سرى باقى ماندهها با هم تركيب مى شود. بـــيهى اسـت كـه سـرى $Y_{t}=Y_{t}^{\prime}+T_{t}$

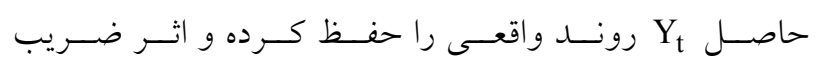
خودهمبستخى نيز حذف شده است.

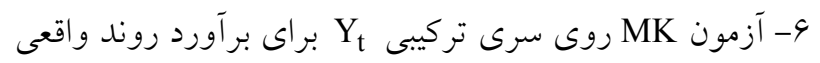

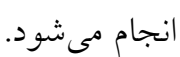

\section{طبقهبندى آب بر اساس ويلكاكس و شولر} طبقهبندى ويلكاكس يكى از مهمترين طبقهبندى بها در زمينه تعيسين

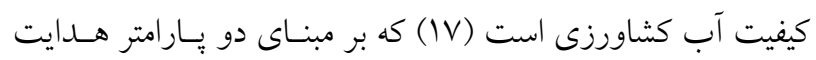

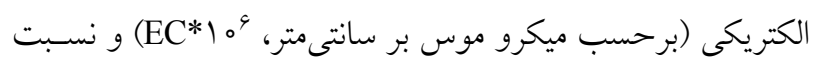

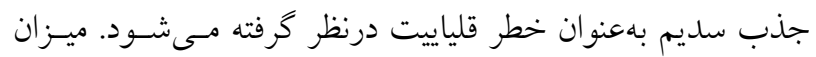
SAR طبق رابطه V با افزايش سديم افزايش مىيابد (r)):

$$
\mathrm{SAR}=\frac{\mathrm{Na}^{+}}{\sqrt{\frac{\left(\mathrm{Mg}^{2+}\right)+\left(\mathrm{Ca}^{2+}\right)}{2}}}
$$

در آب هاى شور، سديم جايكزين كلسيم و منيزيم موجـود روى

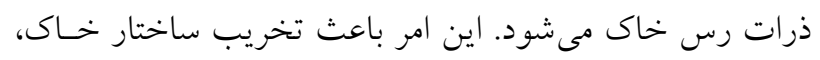

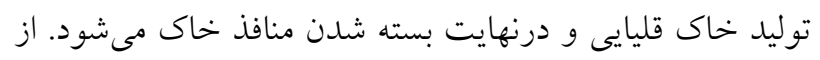

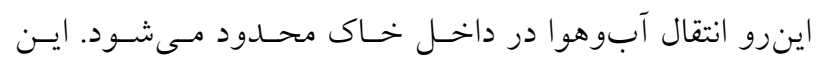

قابل محاسبه است (1) (1): - (1)

$\mathrm{S}=\sum_{\mathrm{i}=1}^{\mathrm{n}-1} \sum_{\mathrm{j}=\mathrm{i}+1}^{\mathrm{n}} \operatorname{sgn}\left(\mathrm{x}_{\mathrm{j}}-\mathrm{x}_{\mathrm{i}}\right)$

$$
\operatorname{sgn}(\theta)=\left\{\begin{aligned}
1 & \text { if } \theta>0 \\
1 & \text { if } \theta=0 \\
-1 & \text { if } \theta<0
\end{aligned}\right.
$$

بـر اى n n آمـاره S داراى توزيـع نرمـال بـوده و ميـانخين و واريانس آن از رابطه (r) بهدست مى آيد:

$\mathrm{E}(\mathrm{S})=0$

$\operatorname{Var}(S)=\frac{n(n-1)(2 n+5)-\sum_{m=1}^{n} t_{m}\left(t_{m}-1\right)\left(2 t_{m}+5\right)}{18}$

كه در آن t تعداد دادههاى يكسـان در دسـته i ام اسـت. آمـاره

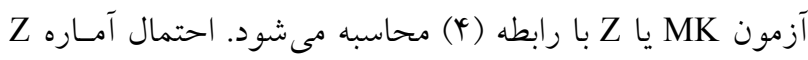

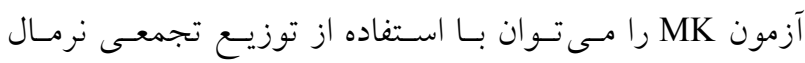

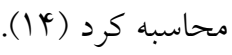

$$
\mathrm{Z}=\left\{\begin{array}{cc}
\frac{\mathrm{S}-1}{\sqrt{\operatorname{Var}(\mathrm{S})}} & \mathrm{S}>0 \\
0 & \mathrm{~S}=0 \\
\frac{\mathrm{S}+1}{\sqrt{\operatorname{Var}(\mathrm{S})}} & \mathrm{S}<0
\end{array}\right.
$$

آزمون MK روى سرى زمـانى هـيش سـفيد شـده بـهـروش

TFPW

روش TFPW-MK براى شناسايى روند در يـك سـرى زمـانى

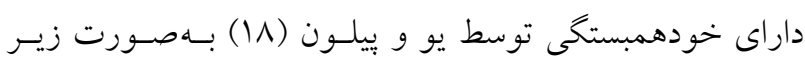

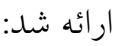

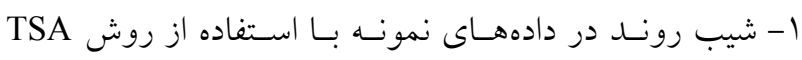
بهصورت زير برآورد مىشود (رابطه ه): $\mathrm{b}=\operatorname{Median}\left(\frac{\mathrm{X}_{\mathrm{j}}-\mathrm{X}_{1}}{\mathrm{j}-1}\right) \quad \forall \mathrm{l}<\mathrm{j}$

r- اخر شيب تقريباً برابر صفر بود آنخاه ديخـــ نيـازى بـهـ ادامـه.

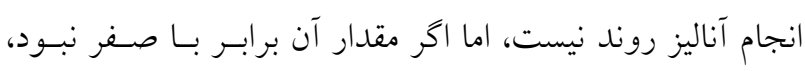

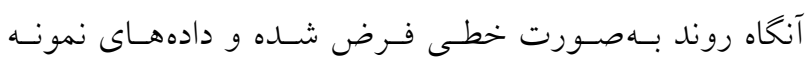

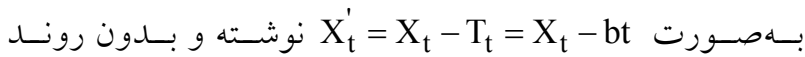

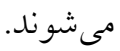

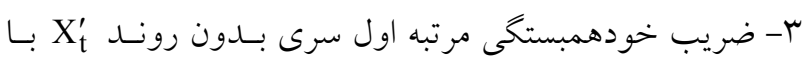

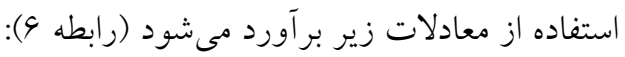




\begin{tabular}{|c|c|}
\hline معادل توصيفى & مقدار شاخص \\
\hline خيلى بد & كمتر از ها \\
\hline بد & $10-r q / 9$ \\
\hline نسبتاً بد & $\mu \circ-\varphi \psi / q$ \\
\hline متوسط & $\varphi \Delta-\Delta \Delta$ \\
\hline نسبتاً خوب & $\Delta Q / 1-V_{0}$ \\
\hline خوب & $\vee \circ / I-\wedge \Delta$ \\
\hline بسيار خوب & بيشتر از هـ \\
\hline
\end{tabular}

$\operatorname{IRWQI}_{\mathrm{GC}}=\left[\prod_{\mathrm{i}=1}^{\mathrm{n}} \mathrm{I}_{\mathrm{i}} \mathrm{W}_{\mathrm{i}}\right]^{\frac{1}{\gamma}} \quad \gamma=\sum_{\mathrm{i}=1}^{\mathrm{n}} \mathrm{W}_{\mathrm{i}}$

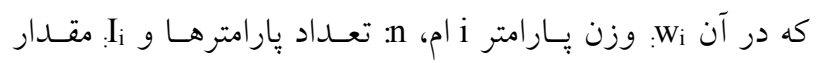
شاخص براى بارامتر i ام است.

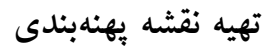

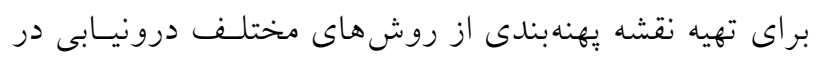

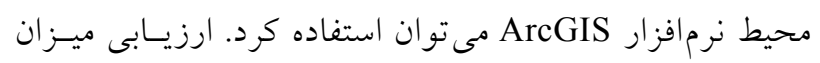

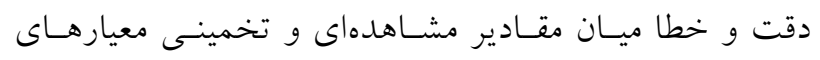

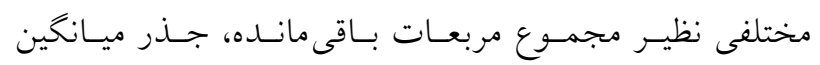
مربعات خطا (RMSE)، استفاده از روش هاى مقايسـه آمـارى مئس

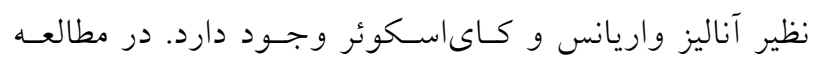

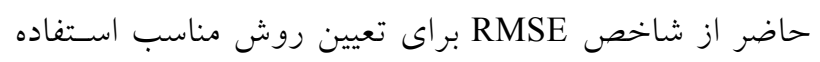

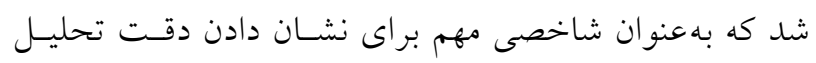

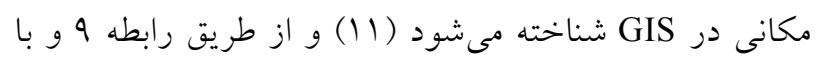

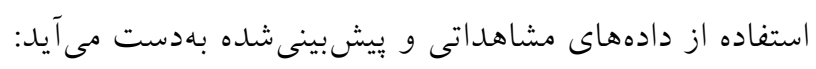
RMSE $=\sqrt{\frac{\sum_{t=1}^{n}\left(x_{i}-\bar{x}\right)^{2}}{n}}$

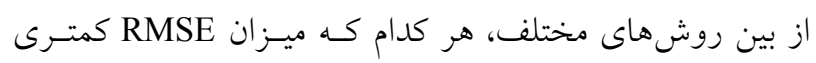

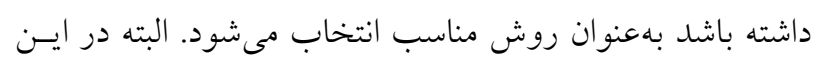

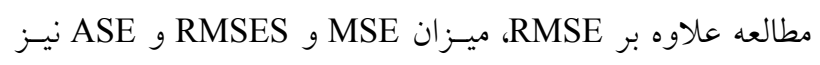
محاسبه شدند.

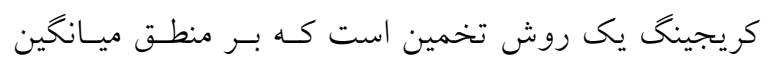

شرايط باعث كاهش بـازدهى محصـولات مسىشـود. در ايسن

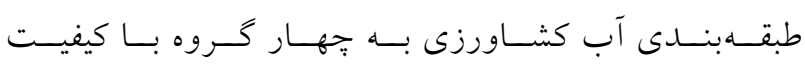

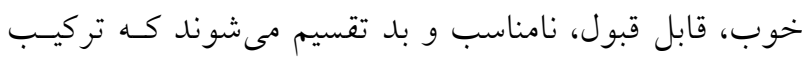

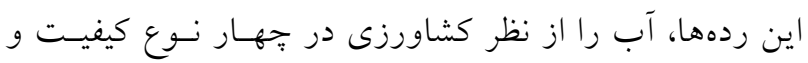
19 رده تقسيم مى كنند: شيرين - براى كشاورزى كاملاً بى ضر كرد

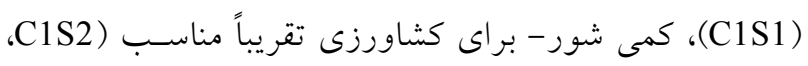

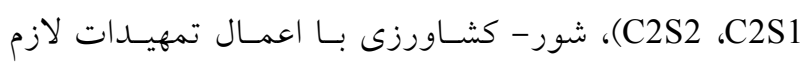

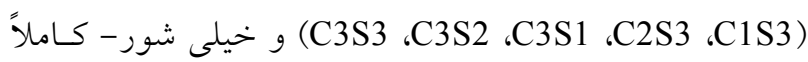

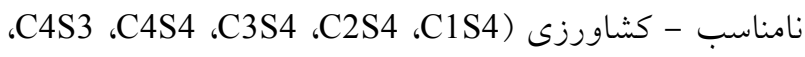

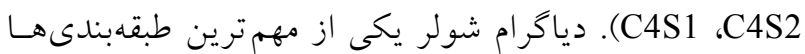
براى بررسى كيفيت آب از نظر شرب اسـتـ. در ايسن نمـودار

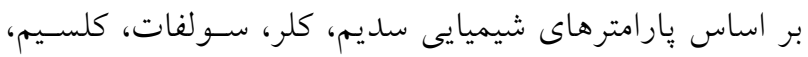
منيزيم و pH آبها از نظر مصرف آشاميدنى تقسيم مى شوند

شاخص كيفيت منابع آب ايران (IRWQI) بزوهشكده علوم محيطى دانشخاه شهيد بهشتى تحت نظـارت

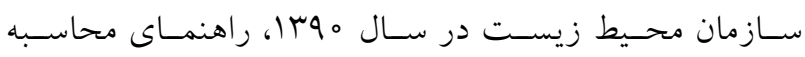

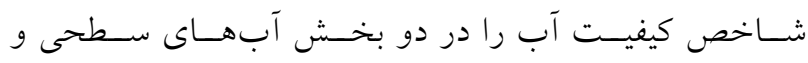

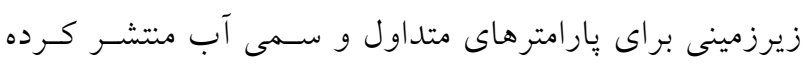

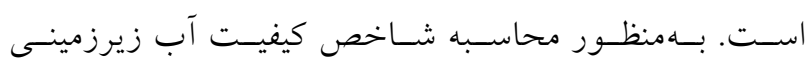

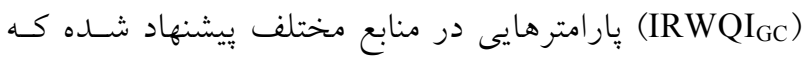

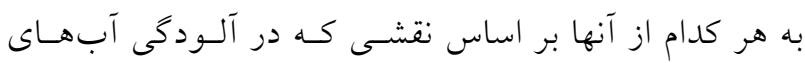

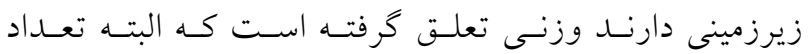
يارامترها مى تواند تغيير كند.

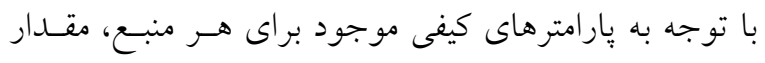

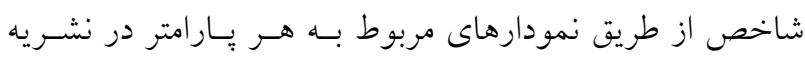

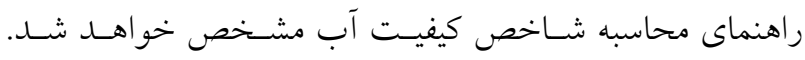

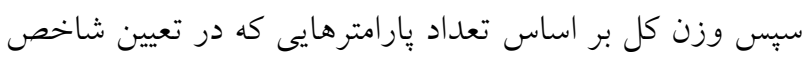

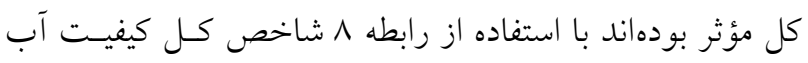

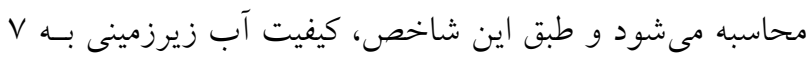

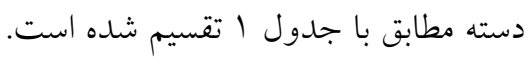




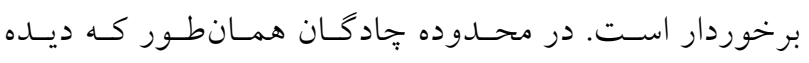

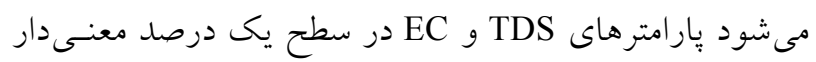

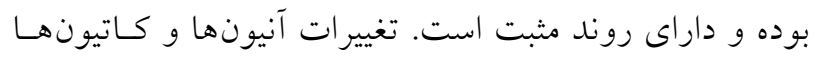

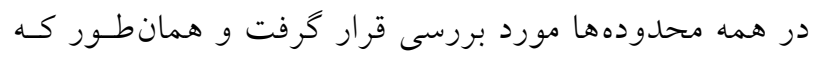

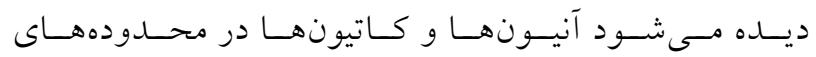

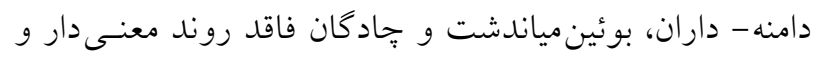
تنها در محدوده جهلخانه داراى روند معنى دار منفى در سطح

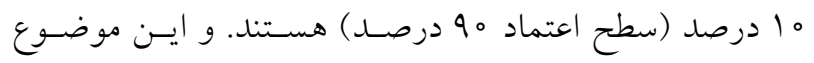

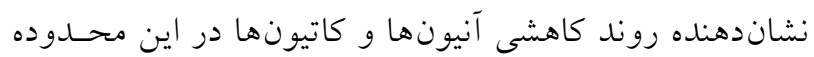

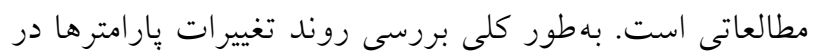

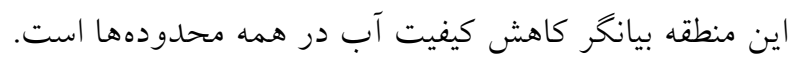

كيفيت منابع آب زيرزمينى براى مصارف كشاورزى و شـرب در آبخوانهاى بالادست سد زايندهرود

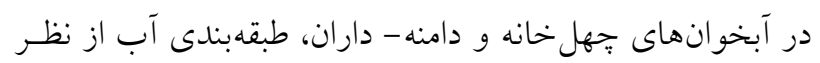
كشاورزى بر اساس طبقهبندى ويلكاكس بهطسور عمــه C2-S1 (كمى شور - مناسب براى كشاورزى) است و درصد كمى نيـز

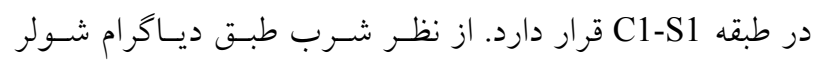
بلهطور عمده خوب و درصد كمى نيز در طبقه قابل قبـول قـرار

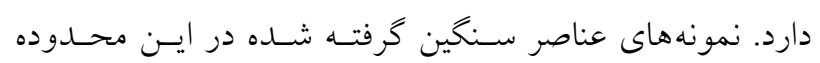

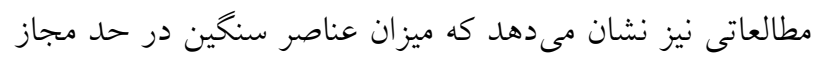

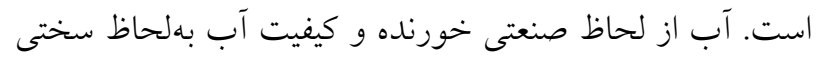

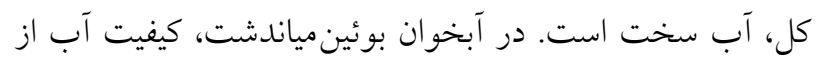

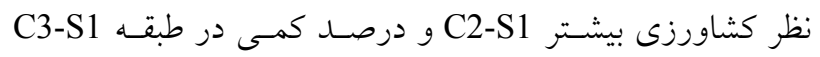

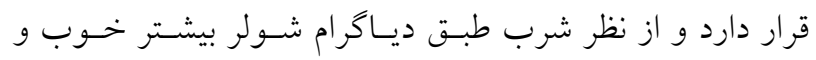

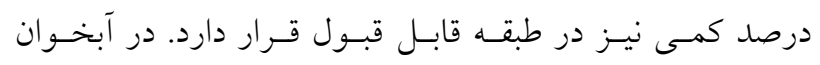

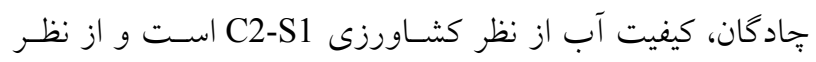

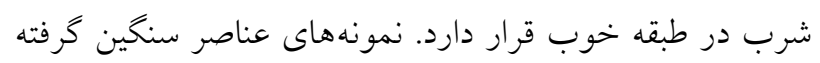

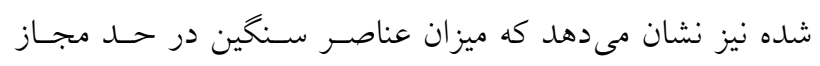

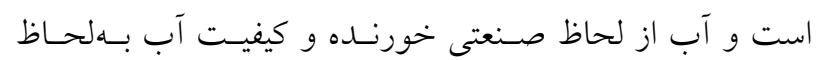

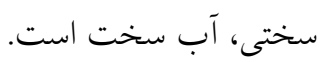

متحرك وزندار استوار است و بهترين تخمين گر خطى ناريب است (V). شرط استفاده از روش كريجينگ آن است كه متغيـر

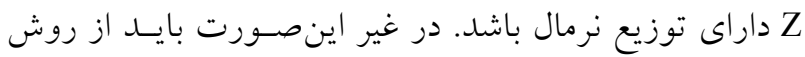
كريجينگ غير خطى استفاده و يا بهنحوى توزيــع متغيــ نرمـال شود. رابطه كلى كريجينگ بهصورت رابطه ه 1 است: $\mathrm{Z}_{(\mathrm{Xi})}^{*}=\sum_{\mathrm{i}=1}^{\mathrm{n}} \lambda_{\mathrm{i}} \mathrm{Z}(\mathrm{Xi})$

كه در آن،

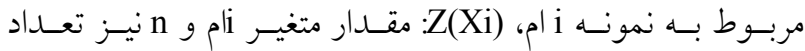
مشاهدات است.

نتايج

روند تغييرات كيفيت منـابع آب زيرزمينـى در آبخــوانهـاى

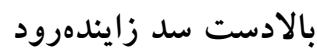

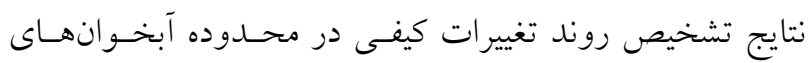

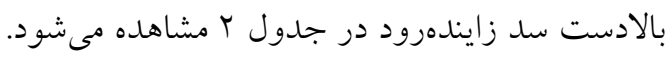
همـانطـور كـه در جــدول r ديسـده مسى شـود ضـرايب

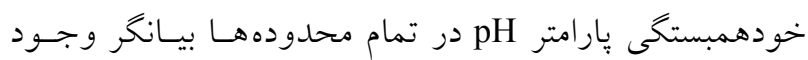

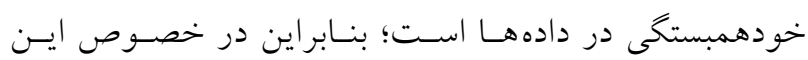

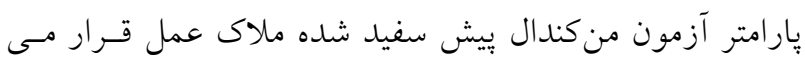

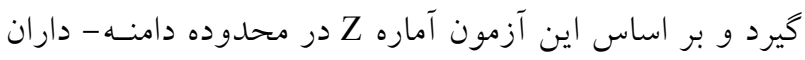

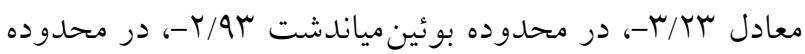

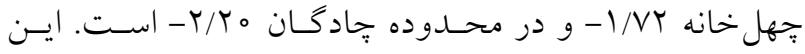
موضوع نشان مىدهد كه يارامتر pH داراى روند منفى معنىدار در سـطح يـك درصسـد در محســدودههــاى دامنـهـ- داران و بوئين مياندشت، در سطح ه 1 درصد در محدوده جهـل خانسه و

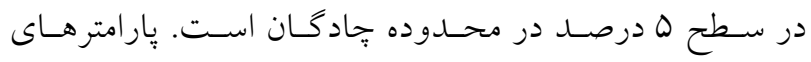

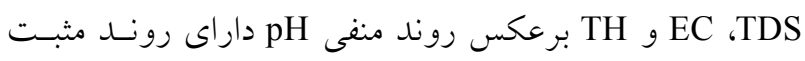

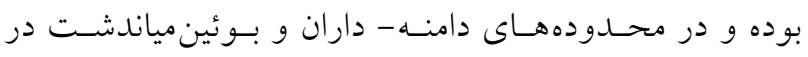

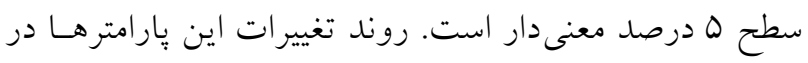
محدوده جهل خانه معنى دار نيست و اين موضوع نشان مىدهد كه اين محدوده از وضعيت بهترى نسبت به ساير محسدودههـا 
جدول r. روند تغييرات بֶارامترهاى كيفى با استفاده از روشهاى من كندال و من كندال بِيش سفيد شده بهروش TFPW

\begin{tabular}{|c|c|c|c|c|c|c|c|c|c|}
\hline \multicolumn{4}{|c|}{ آزمون من كندال } & \multirow{2}{*}{\multicolumn{2}{|c|}{ حد بالا و بايين ضريب }} & \multirow{3}{*}{ خوريب } & \multirow{3}{*}{ شيب } & \multirow{3}{*}{ يار } & \multirow{3}{*}{ نام محدودده } \\
\hline \multicolumn{2}{|c|}{ يش سفيد شده بهروش TFPW } & \multicolumn{2}{|c|}{ بدون بيش سفيد } & & & & & & \\
\hline Z & $\mathrm{P}$ & $\mathrm{Z}$ & $\mathrm{P}$ & حد بِيينى & حد بالايى & & & & \\
\hline W/ & $99 / 90$ & $-r / V I$ & $99 / 41$ & $\circ / \mu \circ \mu$ & $-0 / / 9 \wedge$ & $0 / 94 V$ & $-0 / 0 Y q$ & $\mathrm{pH}$ & \multirow{6}{*}{ دامنه - داران } \\
\hline$T / Y_{0}$ & $Q V / T Q$ & $r / \mu Y$ & $91 / 10$ & $\circ / r \circ r$ & $-0 / 49 \wedge$ & $0 / Y 91$ & $T / \circ Y V$ & TDS & \\
\hline$r / M Y$ & $99 / 10$ & $r / T_{0}$ & $9 V / 11$ & $\circ / \mu \circ \mu$ & $-0 / 49 \wedge$ & - TOY & $r / 019$ & $\mathrm{EC}$ & \\
\hline $1 / 1 r$ & $01 / N r$ & $\mid / T 1$ & $V V / D V$ & $\circ / \mu \circ \mu$ & $-\circ / 49 \wedge$ & $0 /|q|$ & $\circ N T V$ & TH & \\
\hline$-\circ / \mu q$ & $\mu \circ / v 1$ & $-0 / 1 \mathrm{~V}$ & $|r /| 1$ & $\circ / \mu \circ \mu$ & $-0 / 49 \wedge$ & $\circ / T Q$ & 010094 & آنيونها & \\
\hline$-\circ / \Delta V$ & 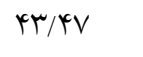 & $-\circ / \wedge$ & G/VA & $\circ / \mu \circ \mu$ & $-0 / / 9 \Lambda$ & $\circ / Y \Lambda$ & $\circ / 0 \circ \circ \mathrm{V}$ & كاتيونها & \\
\hline$-r / 9 r$ & $99 / 90$ & $-\Gamma / 90$ & $99 / Y 1$ & $\circ / r \circ \mu$ & $-0 / / 91$ & $\circ / 4 V V$ & $-0 / 0 Y 9$ & $\mathrm{pH}$ & \multirow{6}{*}{ بوئين مياندشت } \\
\hline$T / Q V$ & $91 / 9 V$ & r & $90 / 0 \circ$ & $\circ / r \circ \mu$ & $-0 / \pi 91$ & $0 / 04 \wedge$ & $r / T \circ D$ & TDS & \\
\hline$T / Q V$ & $91 / 9 V$ & $1 / 9 V$ & $90 / 1 \mathrm{~V}$ & $\circ / \mu \circ \mu$ & $-0 / 491$ & ००५^ & $r / r \Delta V$ & EC & \\
\hline$T / T G$ & $9 V / 90$ & $1 / 44$ & $\Lambda Y / \wedge V$ & $\circ / \mu \circ$ & $-0 / \Gamma q \wedge$ & $-0 / 190$ & 1/०QH & $\mathrm{TH}$ & \\
\hline$-Y / 9 \mu$ & $99 / 11$ & $-0 / 11$ & $9 / 19$ & $\circ / \mu \circ \mu$ & $-0 / 491$ & $-0 / Y \circ Y$ & $-0 / 001$ & آنيونها & \\
\hline$\circ / \Delta V$ & 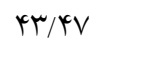 & $0 / r Y$ & $|V / A|$ & $\circ / \mu \circ \mu$ & $-0 / 49 \wedge$ & $-0 / 490$ & ०/००r & كاتيونها & \\
\hline$-I / V T$ & $91 / 00$ & $-1 / \wedge 0$ & $9 Y / 90$ & $\circ / \mu \circ \mu$ & $-0 / 491$ & $\circ / D \circ Y$ & $-0 / 01 \mu$ & $\mathrm{pH}$ & \multirow{6}{*}{ جهل خانه } \\
\hline.$/ 94$ & $90 / 0 Y$ & $0 / M^{\prime}$ & TG/TY & $\circ / \mu \circ \mu$ & $-0 / 49 \wedge$ & $-0 / 010$ & $\circ / \mu \circ \Lambda$ & TDS & \\
\hline $0 / 94$ & $90 / \circ Y$ & $0 / T \Lambda$ & YY/KY & $\circ / \mu \circ \mu$ & $-0 / / 9 \wedge$ & $-0 / 01 \mathrm{~V}$ & o/4GT & $\mathrm{EC}$ & \\
\hline$-0 / 01$ & rq/ro & $-\circ / \wedge \Delta$ & $90 / 11$ & $\circ / \mu \circ \mu$ & $-0 / / q \wedge$ & $-0 / 049$ & $-0 / 9 Y \Delta$ & $\mathrm{TH}$ & \\
\hline$-1 / 1 T$ & $v^{4}$ & $-1 / 99$ & $9 \circ / 4$ & $\circ / \mu \circ \mu$ & $-0 / 4 q 1$ & $-\circ / \circ \Delta \wedge$ & $-\circ / \circ r$ & آنيونها & \\
\hline$-1 / \mu \circ$ & $\Lambda^{\circ}$ & $-1 / 94$ & $90 / 4$ & $\circ / r \circ r$ & $-0 / 4 q \wedge$ & $-0 / 001$ & $-0 / 0 r$ & كاتيونها & \\
\hline$-Y / Y \circ$ & $9 V / 11$ & $-1 / 4 x$ & $\Lambda Y / \Lambda V$ & O/YYI & -o/MTr & $0 / 919$ & $-0 / \circ \uparrow_{\Lambda}$ & $\mathrm{pH}$ & \multirow{6}{*}{ جادگان } \\
\hline$r / 11$ & $99 / 90$ & T/AY & $99 / 0 Y$ & $0 / M Y I$ & -o/krt & $\circ / N \Delta 1$ & $r / 090$ & TDS & \\
\hline$r / 1$ & $99 / 90$ & r/A & $99 / 0 r$ & ס ו & -o/krt & - Mor & $r$ & $\mathrm{EC}$ & \\
\hline I/AY & $q \mu / \circ D$ & T/l。 & $99 / \mu \wedge$ & $0 / M Y I$ & -o/KTY & $\circ / \backslash \wedge \mid$ & I/TYY & $\mathrm{TH}$ & \\
\hline - /QH & 41 & $\circ / \mathrm{VV}$ & $\Delta 9$ & O/MYI & -o/krt & $-\circ / \circ \Delta \varphi$ & .011 & آنيونها & \\
\hline$-0 / Y \mu$ & 11 & $\circ / \mu \wedge$ & r。 & $0 / \mu r \mid$ & -o/Mrr & $-0 / 0 \mu k$ & ०/००Y & كاتيونها & \\
\hline
\end{tabular}

در دادههاى آب و فاضلاب روستايى و آب و فاضـلاب شـهرى

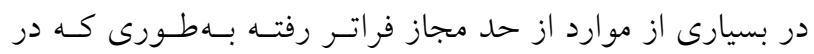
دادههاى آب و فاضلاب روستايى به هو ميلى گـرم در ليتـر و در دادههاى آب و فاضلاب شهرى حتى بـه بو ميلسى خـرم در ليتـر

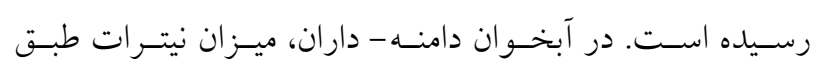

تهيـه نقشــه بهنــهنــدى نيتـرات و شـاخص IRWQIGC در محدوده آبخوانهاى بالادست سد زايندهرود

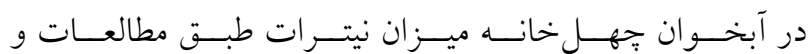
اندازه كيرىهاى انجام شده توسـط دانشـحاه اصـفهان در طـرح تعيين حريم كيفى در حد مجاز بوده و اين در صورتى است كـه 
جدول r. مشخصات اجراى روش كريجينگ در محدوده آبخوانهاى بالادست سد زايندهرود

\begin{tabular}{|c|c|c|c|c|c|c|}
\hline$\overline{A S E}$ & RMSES & MSE & RMSE & بهترين نوع & مدل & داده \\
\hline $\mid N / F V$ &.$/ 91 Y$ & $0 / 0 \mu r$ & $19 / 94$ & Stable & Simpel & $\mathrm{NO}_{3}$ \\
\hline$\| / 4 \wedge$ & $0 / 941$ & $-0 / 0 r_{q}$ & $10 / 01$ & J-Bessel & Ordinery & IRWQIGC \\
\hline
\end{tabular}

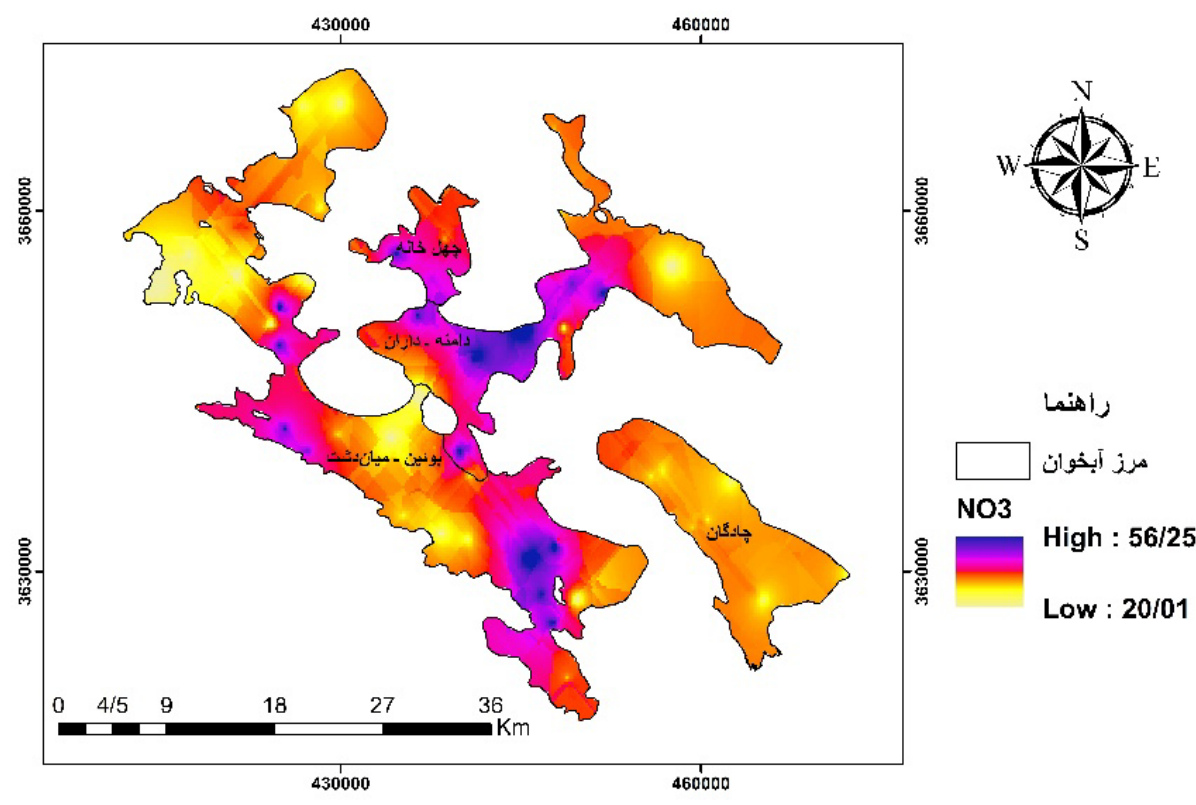

شكل f. نقشه بِهنهبندى نيترات در محدوده آبخوانهاى بالادست سد زايندهرود (هوس|)

اندازهگيرىهاى دانشخاه اصفهان در حد مجاز بوده و حسداكثر نيترات مشاهده شده در فصـل تـر معـادل س rV/IM و در فصـل خشـك Vr ميلسى خــرم در ليتـر اسـت و در دادههــاى آب و فاضـالاب روسـتايى بـه ؟ آس و در دادههـاى آب و فاضـلاب

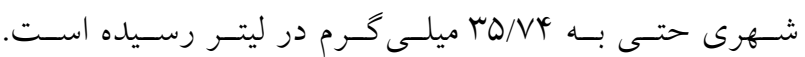

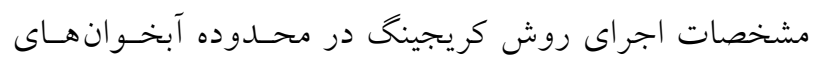

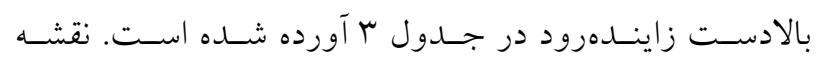
يُهنهبندى نيترات در شكل ب آورده شده است. همانطور كه در شكل f مشاهده مىشـود، مقــادير متوسط لمط نيترات بهترتيب در آبخــوانهـاى دامنـهـ- داران و جهـل خانـه و بوئينمياندشت بالاتر است و نشان مىدهد كه منابع آلوده كنتـده در اين مناطق بيشتر بوده اما جاد گان نسبت به سه آبخوان ديخـر كه در مجاورت يكديخر قرار گرفتهاند، مقــار متوسـط نيتـرات كمترى دارد.
اندازه كيرىهاى انجام شده توسـط دانشـحاه اصـفهان در حسد مجاز نبوده و حداكثر نيترات مشاهده شده در فصل تر معسادل

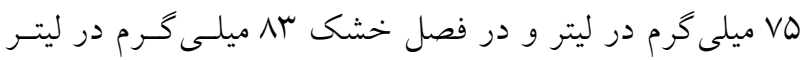
است. همجنين ميزان نيترات در آزمايشهـاى آب و فاضـلاب روستايى و آب و فاضلاب شهرى در بسيارى از موارد از حســ

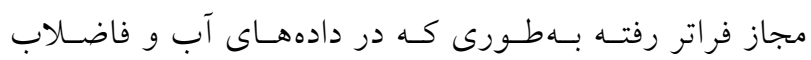
روستايى به 99 و در دادههاى آب و فاضلاب شهرى بـه س/ M ميلى گرم در ليتر رسـيده اسـت. در آبخـوان بـوئينمياندشـت،

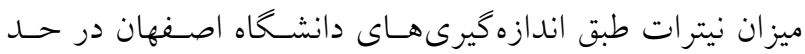
مجاز نبوده و حداكثر نيترات مشاهده شده در فصل تر معـادل

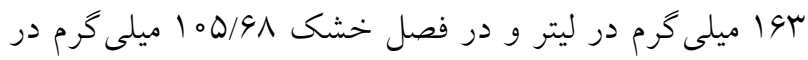
ليتر است و در دادههاى آب و فاضلاب روسـتايى بـه VY/N و در دادههاى آب و فاضلاب شهرى حتى به / /هی ميلى گـرم در

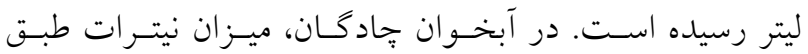


جدول F. مشخصات آمارى IRWQIGC در محدوده آبخوانهاى بالادست سد زايندهرود

\begin{tabular}{|c|c|c|c|c|}
\hline متوسط IRWQIGC & مينيمم IRWQIGC & ماكزيمم IRWQIGC & واريانس IRWQIGC & محدودهه \\
\hline$\Delta \circ / T$ & 4 & 99 & $101 / 4$ & جهل خانه \\
\hline$\varphi \varphi / 4$ & $r M / 9$ & Vr & $1 r q / \Lambda$ & دامنه - داران \\
\hline$\Delta Y / \Delta$ & TV/V & VG & $14 r / 0$ & بوئينمياندشت \\
\hline $14 / 9$ & 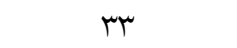 & 09 & $09 / \mathrm{V}$ & جادگان \\
\hline
\end{tabular}

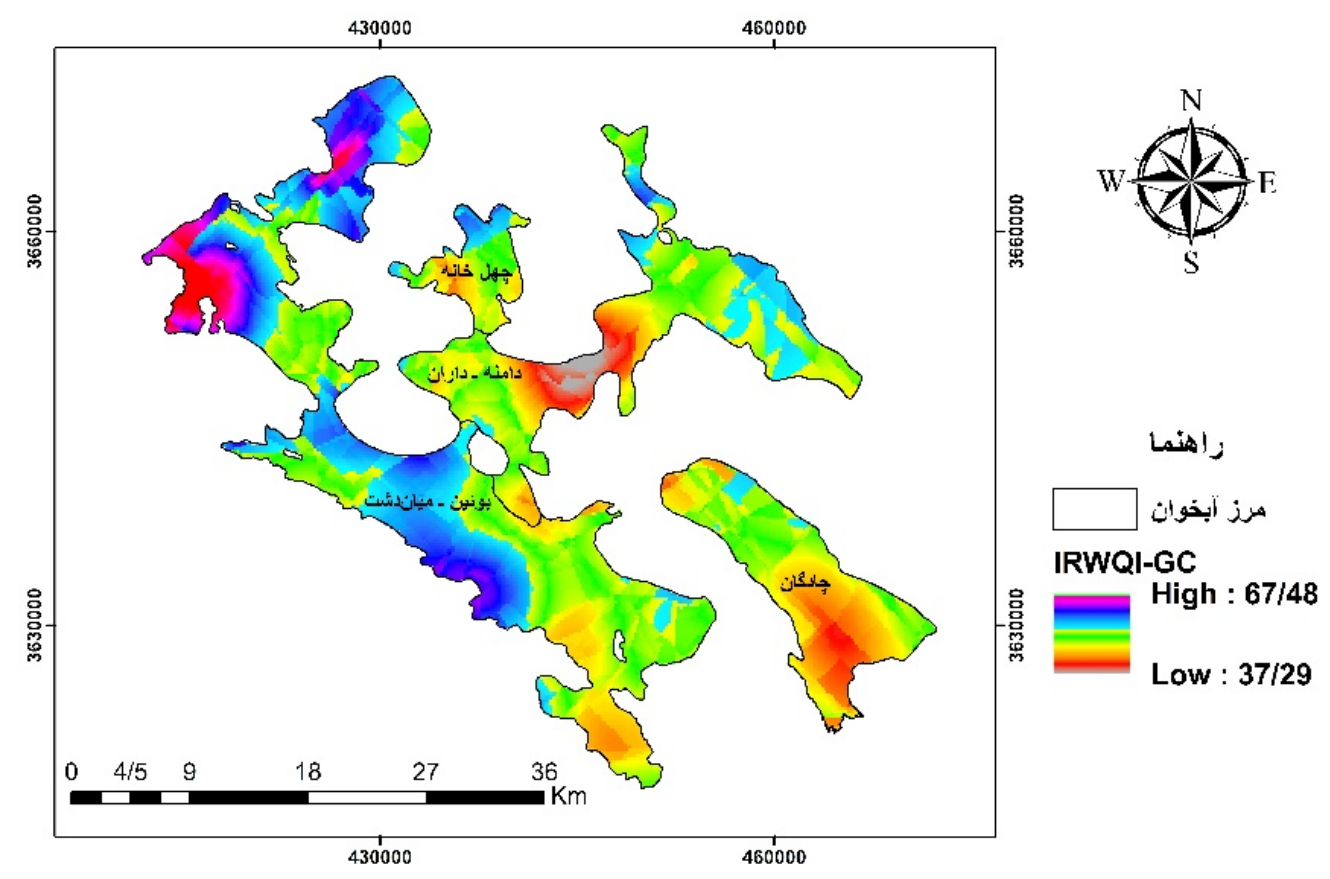

شكل ه. نقشه يهنهبندى شاخص IRWQIGC در محدوده آبخوانهاى بالادست سد زايندهرود (0هץr)

قسمتهاى اين آبخوان است و در واقع كيفيت آب با توجه بـهـ

اين شاخص كيفى در قسمتهاى جنوبى جادگان كمتر است.

بحث و نتيجه گيرى

در اين بززوهش، روند تغييرات بِارامترهـاى كيفـى منـابع آب

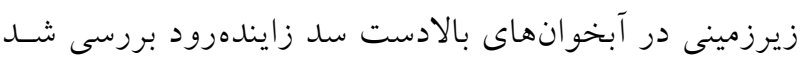
و همجنين كيفيت آب از نظـر مصـارف شـرب و كشـاورزى مورد بررسى قـرار كرفـت و نيـز شـاخص IRWQI محدوده آبخوانهاى بالادست سد زايندهرود محاسبه شـــ. در اين محدوده كيفيت آب با كذشت زمان، كاهش يافته است و

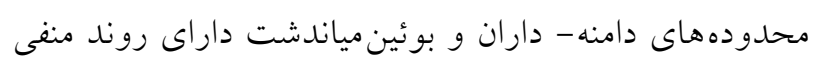

IRWQIGC محاسبه شاخص

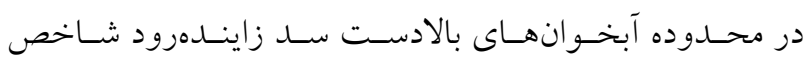
محاسبه شد كه مشخصات آمارى اين اندازه كيرىهـ در جدول با نشان داده شده است. بيهنهبنـدى شـاخص در ايسن محدوده نيز در شكل ه آورده شده است. همانطـور كـه در شـكل ه مشـاهده مسى شـود در آبخــوان بوئينمياندشت در قسمتهاى جنوبى و شرقى، كمتـرين مقـدار شاخص مشاهده مىشود. در آبخوان جهل خانه در قسـمتهـاى جنوبى، مركزى و غربى و در آبخـوان دامنـه- داران در قسـمت هاى مركزى كمترين مقدار شاخص مشاهله مىشـود. همجنــين مقدار شاخص در قسمتهاى جنـوبى زجادگَـان كمتـر از سـاير 
شناسايى منابع آلاينده آب در اين محدودهها، نسبت به كنترل

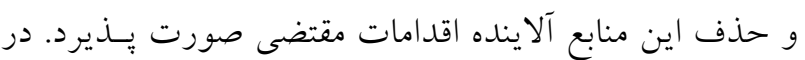

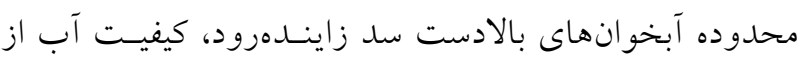

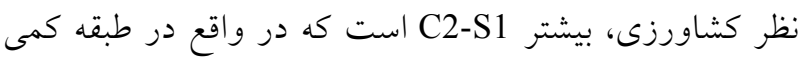

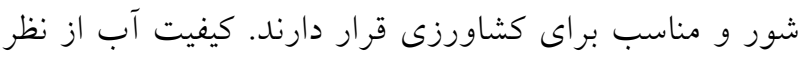

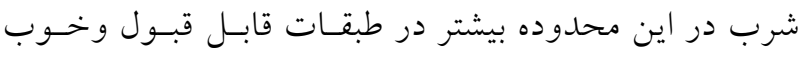

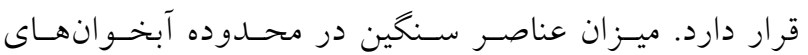
مطالعاتى در حد مجاز است. آب از لحاظ صنعتى خورنـده و

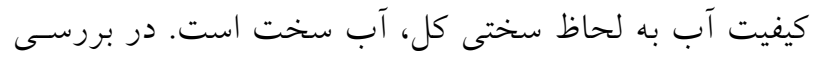

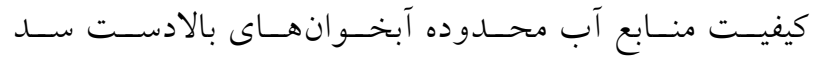
زاينـادرود بــر اســاس شـاخص كيفيـت منسابع آب ايسران

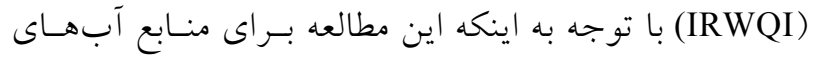

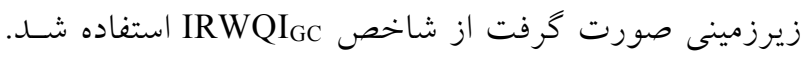

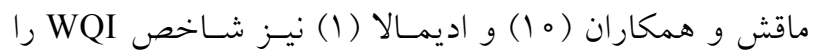
براى بررسى كيفيـت منـابع آب، مناسـب برشـمردند امــا در مطالعه حاضر با توجه به اينكه منطقه تحقيـق در ايـران قـرار

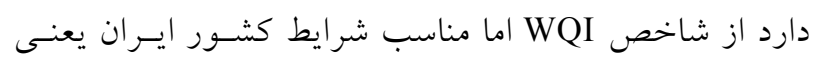
اسـتفاده شــ، همــانطـور كـه در مطالعـه اميـرى و

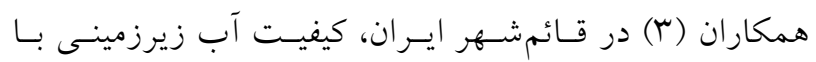

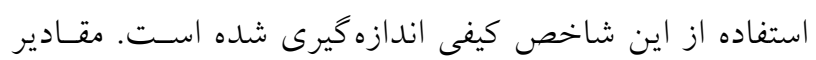

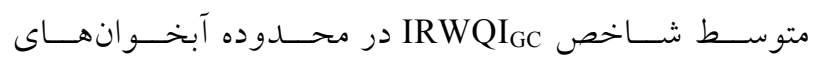

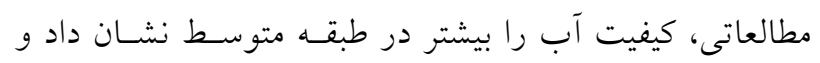
البته در مواردى مقادير مينيمم شاخص در آبخوانهاى دانئ دامنه-

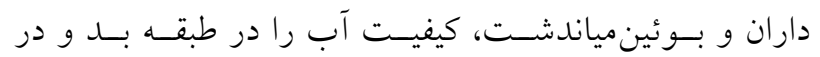

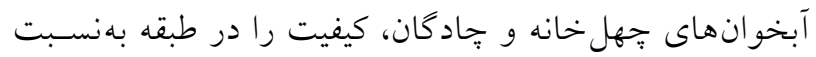
بد نشان داد. كمترين مقدار متوسط شـاخص كـه در طبقـات

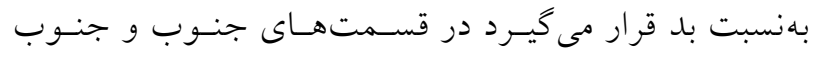
غرب بوئينمياندشت، قسـمت هـاى مركـزى دامنـه- داران و

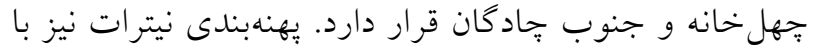
استفاده از روش كريجينگ انجام شد. بيشترين مقدار نيتـرات

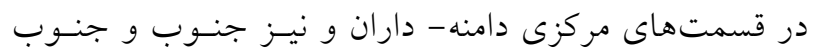

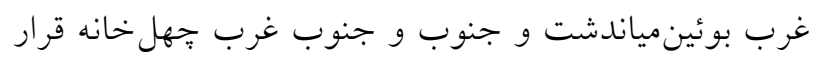

شديدترى نسبت به دو محدوده ديخر در طى زمان هستتند و

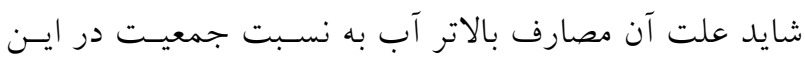
محدودهها باشد كه علل اين موضوع مسى توانــد در مطالعـات

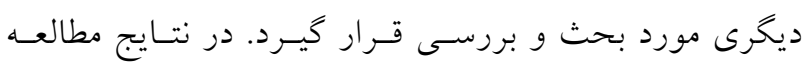

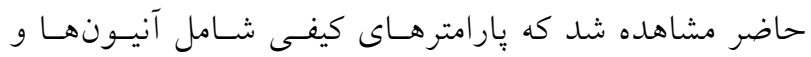

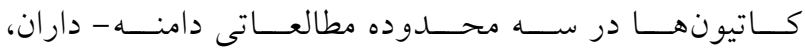

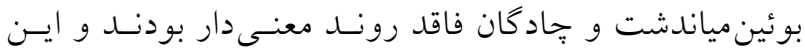
موضوع نشان مى دهد افزايش EC در اين محدودهها ناشى از

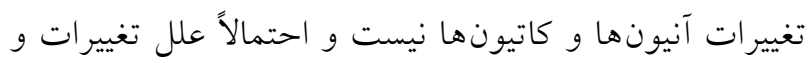
افزايش EC عللى غير از عوامل زمسينشناسى داشـته اسـت.

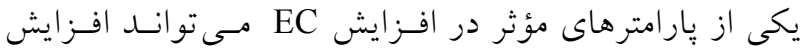

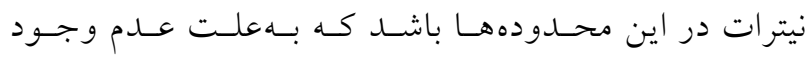

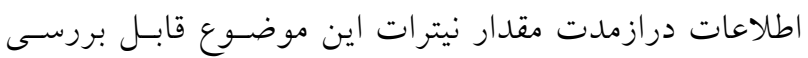
نيست. اما شـواهد و همجنِـين افـز ايش استفاده از كودهـاى

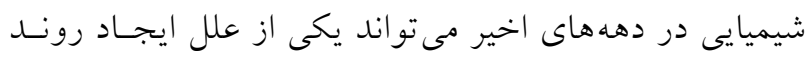

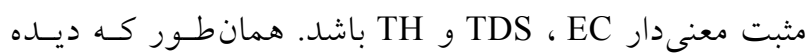
شد در تمام محدودههها pH داراى روند منفى معنسى دار بـوده

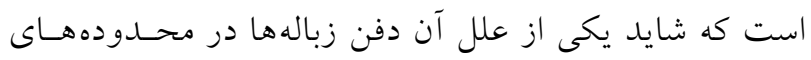

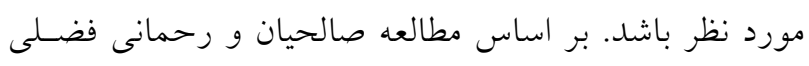

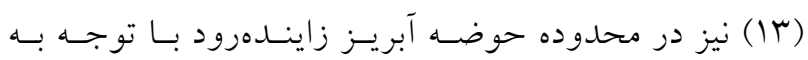

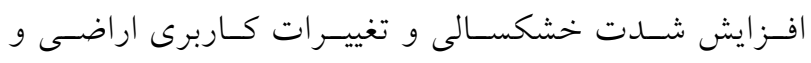

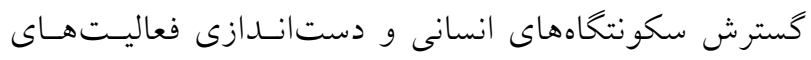

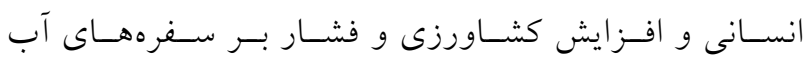

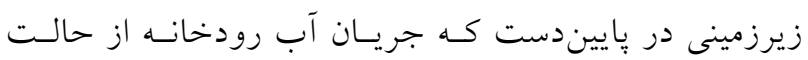

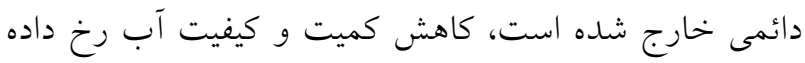

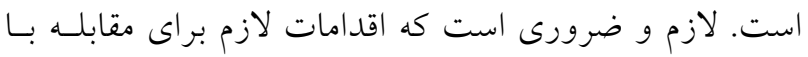

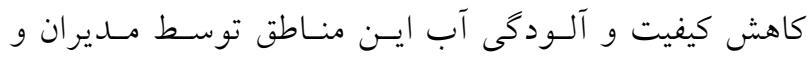

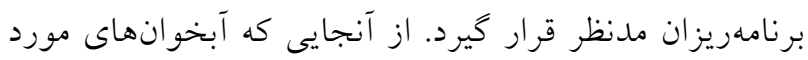

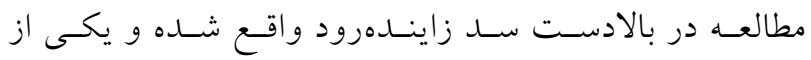

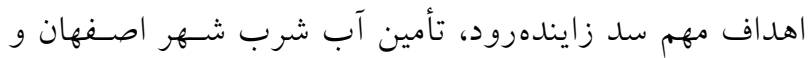
ديخر شهرها و روستاهاى باييندست اين سد است، بنـابراين

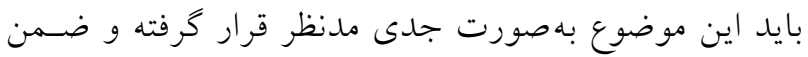




$$
\begin{aligned}
& \text { توان به زهكشـى ذوب آهـن، يُسـاب كارخانـه يلسى اكريـل، } \\
& \text { دارد. بالوشا (Y) نيز روش كريجينگ را روشى مناسـب بـراى } \\
& \text { يساب كارخانه نساجى و تصفيهخانه اصفهان اشـاره كـرد. بـا } \\
& \text { تهيه نقشه يهنهابندى معرفى كردند زيرا كـه نتـايج حاصـل از } \\
& \text { توجه به توسعه مراكز شهرى و صنعتى در اطراف زاينـدهرود } \\
& \text { كريجينگ از نظر واريانس مكانى، موقعيت مكانى، موقعيت و } \\
& \text { درصورتى كه اقدام جدى و سريع صورت نخيرد آلـودگى در } \\
& \text { توزيع نمونهها قابل اعتماد است و نسبت به روش هاى ديخر، } \\
& \text { بيشتر مورد توجه محققين در مطالعـات آب زيرزمينسى بـوده }
\end{aligned}
$$

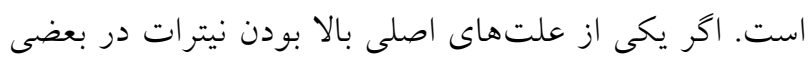

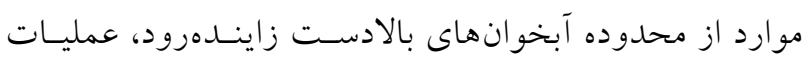

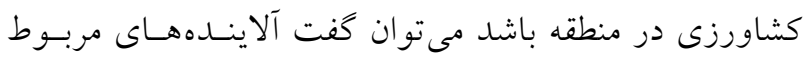

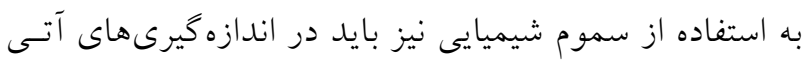

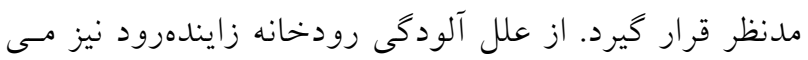

\section{منابع مورد استفاده}

1. Adimalla, N. 2019. Controlling factors and mechanism of groundwater quality variation in semiarid region of South India: an approach of water quality index (WQI) and health risk assessment (HRA). Environmental Geochemistry and Health 1-28.

2. Alizadeh, A. 2006. Principles of Applied Hydrology. Twenty-Fifth Printing. Astan Ghods Razavi Publications. Mashhad. (in Farsi).

3. Amiri, F., T. Tabatabaei and S. Valipour. 2018. Assessment and analysis of groundwater quality in landfills using IRWQI $_{\mathrm{GC}}$. Journal of Soil and Water Sciences 22(1): 211-226. (In Farsi).

4. Baalousha H. 2010. Assessment of a groundwater quality monitoring network using vulnerability mapping and geostatistics: A Case study from Heretaunga Plains, New Zealand. Agricultural Water Management 97: 240-246.

5. Effendi, H. 2016. River water quality preliminary rapid assessment using pollution index. Procedia Environmental Sciences 33: 562-567.

6. Farzadkia, M., Y. Poureshgh and A. Joneidijafari. 2016. Water quality of Aghlaghan River based on NSFWQI index and zoning it by Geographic Information System (GIS). International Journal of Occupational and Environmental Health 1(1): 68-78. (In Farsi).

7. Gaus, I., D. G. Kinniburgh, J. C. Talbot and R. Webster. 2003. Geostatistical analysis of arsenic concentration in groundwater in Bangladesh using disjunctive Kriging. Environmental Geology 44: 939-948.

8. Hoseinzadeh, E., N. Rahimi, A. R. Rahmani and L. Ezzati. 2013. Quality assessment of takab Sarugh River right branch by wilcox index and its zoning using geographical information system. Journal of Mazandaran University of Medical Sciences (JMUMS) 23(103): 77-87. (In Farsi).

9. Kulkarni, A. and H. Von Storch. 1995. Monte Carlo experiments on the effect of serial correlation on the MannKendall test of trend. Meteorologische Zeitschrift 4(2): 82-85.

10. Magesh, N., S. Krishnakumar, N. Chandrasekar and J. P. Soundranayagam. 2013. Groundwater quality assessment using WQI and GIS techniques, Dindigul district, Tamil Nadu, India. Arabian Journal of Geosciences 6: 4179-4189.

11. Nazarizadeh, F., B. Ershadian, K. ZandVakili and M. Nouriemamzade'i. 2006. Investigating the variations in groundwater quality in Balarood plain in Khuzestan province originally published as an ASCE 1981 Water Forum Conference Proceedings. (in Farsi).

12. Richards, L. A. 1954. Diagnosis and improvement of saline and alkali soils. Soil Science 78: 154.

13. Salehian, S. and A. Rahmani Fazli. 2018. Investigation of environmental consequences of water resources instability in Zayandehrood river basin. Journal of Natural Geography Research 50(2): 391-406. (In Farsi).

14. Sabziparvar A. and M. Shademani. 2011. Analysis of the trend of evapotranspiration and reference using Mann Kendall and Spearman test in arid regions of Iran. Water and Soil Journal (Agricultural Sciences and Technology) 25(4): 824 - 834. (In Farsi).

15. Torabi Pudeh, H. and S. Imamgholizadeh. 2014. Investigating the trend of river discharge changes in Lorestan province using TFPW-MK method. Journal of Applied Geosciences Research 14(35): 73-93. (In Farsi). 
16. Turkman, M., A. Noroozi and M. Hemayi. 2019. The trend analysis of climate parameters of Khuzestan province using the Man-Kendall test (TFPW-MK). Journal of Environmental Science Studies 4(1): 884-895. (In Farsi).

17. Wilcox, L. V. 1955. Classification and Use of Irrigation Water. USDA, Circular 969. Washington, DC. USA.

18. Yue, S. and P. Pilon. 2002. The influence of autocorrelation on the ability to detect trend in hydrological series. Hydrological Processes 16(9): 1807-1829. 


\title{
Evaluation of Quality Changes in the Groundwater Resources and IRWQIGC Upstream of Zayandehrood Dam
}

\author{
H. Torabipoudeh ${ }^{1}$, H. Yonesi ${ }^{1 *}$ and A. Arshia ${ }^{2}$
}

(Received: June 2-2019 ; Accepted: September 8-2019)

\begin{abstract}
Understanding the quality of groundwater resources, which are the largest available freshwater reservoir, is one of the needs in planning and developing water resources. The purpose of this research was to study the quality changes of groundwater resources in the upstream aquifers of Zayandehrood Dam (1995-2016) and to evaluate water quality in terms of drinking and agricultural consumption and evaluation of IRWQIGC. For this purpose, EC, TDS, SAR, PH, $\mathrm{TH}, \mathrm{Cl}, \mathrm{CO}_{3}, \mathrm{Ca}, \mathrm{Mg}, \mathrm{Na}, \mathrm{K}, \mathrm{HCO}_{3}$ and $\mathrm{NO}_{3}$ parameters and heavy elements including zinc, copper, lead, cadmium and arsenic were investigated from laboratory samples. In the upstream aquifers of the Zayandehrood Dam, the water classification was mainly agricultural in the C2-S1 range, and it was generally acceptable in the drinking classes. The amount of heavy elements was allowed. The average amount of nitrate in the Chehelkhaneh, Damanehdaran, BoeinMiandasht and Chadegan aquifers was calculated to be 43.77, 48.08, 35.53 and $26.36 \mathrm{mg} / \mathrm{l}$, respectively, and the maximum nitrate levels in these areas, however, were often exceeded. Nitrate zoning and IRWQIGC were performed by the kriging method. The lowest index values, which fell into relatively poor classes, were in the south and southwestern parts of Boein-Miandasht and south and south-west of the Chehelkhaneh, and in the central parts of Damanehdaran, and the south of Chadegan.
\end{abstract}

Keywords: Groundwater, IRWQIGC, Kriging, Zayandehrood

1. Department of Water Engineering, Faculty of Agriculture and Natural Resources, Lorestan University, Khoramabad, Iran.

2. Department of Water Engineering, Faculty of Agriculture and Natural Resources, Lorestan University, Khoramabad, Iran.

*: Corresponding author, Email: yonesi.h@lu.ac.ir 